\title{
A MORTE EM HILDA HILST
}

\author{
Joseane Aguiar NOVAIS ${ }^{1}$ \\ Marcello MOREIRA ${ }^{2}$
}

\begin{abstract}
Resumo: O presente artigo discorre sobre o livro Da morte. Odes mínimas, de Hilda Hilst, e tem como matéria o tratamento dado à morte em suas pequenas odes, que fazem parte de uma obra perturbadora em virtude do posicionamento singular da criatura que as escreveu, denominada pela crítica como voluptuosa. No referido livro, a autora trata da finitude da vida de maneira singular, pensando-a sem querer ultrapassá-la, ressaltando seu processo lento e contínuo, que coroa toda uma existência e que é algo íntimo, sereno e natural. Visão bastante distinta daquela pessimista, apresentada durante toda a tradição poética que tratou da vanidade da vida, em que a morte era vista como sombria, dolorosa, provocadora de temor.
\end{abstract}

Palavras-chave: Hilda Hilst. Morte. Odes. Poesia.

O presente estudo é dedicado ao livro Da morte. Odes mínimas, publicado pela primeira vez em 1980, por Hilda Hilst, poeta, como gostava de ser chamada, que ajuizamos ser uma das melhores escritoras do século $\mathrm{XX}$, atuando como "um lobo solitário" no cenário literário da última metade da referida centúria. Hilda Hilst, sem se filiar a nenhuma escola, mostrou desde as primeiras obras seu diferencial em relação ao que se vinha produzindo até então, para quem a morte também despertou interesse e curiosidade, tornando-a matéria do seu poetar, tal como uma tradição poética longuíssima assim o fez. Sua erudição era notável, conhecedora de uma vasta tradição que ia desde poemas bíblicos a cantigas galaico-portuguesas, poesia mística, canção petrarquista, novela epistolar libertina, idílio árcade, entre outros, aos quais podemos acrescer, como

\footnotetext{
${ }^{1}$ UESB - Universidade Estadual do Sudoeste da Bahia - Departamento de Estudos Linguísticos e Literários. Vitória da Conquista - Bahia - Brasil. 45700-000 - ascon@uesb.br

${ }^{2}$ UESB - Universidade Estadual do Sudoeste da Bahia - Departamento de Estudos Linguísticos e Literários. Vitória da Conquista - Bahia - Brasil. 45700-000 - moreira.marcello@gmail.com
} 
pontuou Alcir Pécora (2000, p. 11), outros grandes ícones do século XX: obras de Rilke, com sua imagética sublime; o fluxo de consciência de Joyce; Beckett e sua cena minimalista; o sensacionalismo de Pessoa etc.

Cristiane Grando, uma das pioneiras nos estudos sobre Hilda Hilst, define-a como uma das fundamentais protagonistas da paisagem literária brasileira e de língua portuguesa do seu século; uma poeta culta, lúcida, consciente das suas ações e palavras, com amor fervoroso pela originalidade. "Toda a sua obra registra um intenso trabalho de linguagem e musicalidade, um imaginário poético no qual questionamentos metafísicos se mesclam com fatos cotidianos" (GRANDO, 2009, p. 323). Tudo isso se refletiu não só em seus poemas, mas em diversos outros textos também reconhecidos por sua excelente qualidade: prosa, teatro e crônicas. Obras bastante diferentes entre si, cujas temáticas perpassam pela política do momento em que vivia, pela metafísica, pelo sexo, às vezes bem explícito, e que são bem singulares, tal qual seus poemas o são.

Um dos seus méritos está justamente, para Souza (2009, p. 264), em sua desenvoltura em passar pelos gêneros literários. Sua produção envolve, como apontado, os três gêneros literários: lírico, dramático e prosaico, resgatando, ainda segundo Souza, a tradição clássica e reciclando-a a partir de conceitos modernos. Tudo isso tornou sua obra bastante rica e despertou o interesse de grandes nomes da crítica literária e amantes da boa poesia; e fez com que, segundo opinião contida no Caderno de Literatura Brasileira do Instituto Moreira Salles dedicado à Hilda, sua obra tivesse poucos rivais, neste ou em qualquer tempo ou espaço. Com tudo isso, no entanto, sua obra não foi muito lida, nem bem aceita, muito menos bem compreendida enquanto a autora vivia.

E Hilda se lamenta, sem parar, deixando-nos entre a piedade (que no caso de uma obra tão magnífica, é ofensiva) e a indiferença também odiosa, talvez o cansaço, e certamente a impotência. Os livros de Hilda Hilst se desviam dos padrões literários dominantes e não têm qualquer interesse em neles se confinar. (CASTELLO, 1994, p. 100).

Para Dias (2009, p. 23), essa obra de Hilda Hilst, seja poesia ou prosa, desde sua estreia no cenário brasileiro, mostrou-se perturbadora em virtude do posicionamento singular do sujeito dessa escritura denominada voluptuosa. Já José Castello afirma não ser formal ou social, mas vital. Sendo assim, um diferencial no tempo em que escreveu, tempo em que se pedia clareza, tempo em que ela se apresentava opaca, incompreensível 
para muitos. Hilda, no entanto, não estava disposta a se adaptar ao "gosto do mercado"; pelo contrário, como aponta Castello (1999), lança-se em uma viagem para fora das normas, distanciando-se das expectativas e causando, muitas vezes, espanto no leitor de sua época.

Em relação à morte, matéria dos poemas apresentados no livro discriminado, segundo Guido (apud CINTRA; SOUZA, 2009, p. 15), Hilst a pensa sem querer ultrapassá-la, em um processo lento de esvaecimento e heroísmo, que coroa toda uma existência, como observaremos quando da análise de seus poemas. Essa finitude constitui para a poeta, então, uma das nuances do autoconhecimento, através de uma travessia no tempo. Nessa obra, não demonstra temor da morte. Sua posição perante o término da vida é bastante distinta daquela permeada por valores estoicos e cristãos. "A mentalidade antiga se sustenta na ideia prévia, ou modelo de perfeição inatingível, que, por não se consumar, conforma a existência com a promessa de salvação na vida após a morte" (GUIDO, 2009, p. 201).

Além disso, essa mentalidade mostra-se pessimista, pois toma a vida humana pela sua duração, apontada como breve, questões distintas das abordadas por Hilst em $D a$ morte. Odes mínimas, obra em que há, para Souza, uma assustadora intimidade com a morte, que se anuncia de forma serena e natural. Segundo Albuquerque (2011, p. 102), a autora faz, nessa obra, uma constante perquirição sobre a morte, que pode ser sintetizada em duas questões: como a morte se manifesta? Ela é construída ao longo da vida?; e em que o sujeito-lírico se entrega à morte com luxúria e volúpia, com altivez. Mesmo tendo consciência da presença da morte, que nos acompanha desde o nascimento e que a "todo momento nos espia”, o morrer para a poeta é, na verdade, um esvaecer. Ato antecipado em seus poemas, cujo recurso utilizado para a sua fatura, consoante Albuquerque (2011), não é o lamento da morte do outro, mas uma abordagem direta da morte do eu, o que não significa, de acordo com Guido (2009), uma consumição dos dias nem a corrosão da existência. Nas palavras do autor: "não se trata da cultura da morte, que fixa o último evento e o tem como certeza para aterrorizar os que não se conformam com os limites estreitos da racionalidade" (GUIDO, 2009, p. 205).

Desse modo, Hilda Hilst distancia-se em muito da poesia moral seiscentista, cuja função admonitória a fazia lembrar constantemente aos homens sua condição mortal e vida breve com o intuito de exortar acerca da busca pelas coisas celestes. Hilda Hilst, 
segundo Guido (2009), não vê motivo de desespero por causa da incerteza da alma. Para o autor, a alma precisa conhecer a si mesma para conseguir alçar-se para além da existência humana, o que é bastante distinto daquilo pregado pela Igreja durante séculos. Nas suas odes mínimas, há uma estreita relação entre poesia e morte. Aquela, para Pécora (2003), se determina justamente por um olhar que tem a morte no centro, pela precisão de notar o fosso no meio do gozo. Para ele, ainda, a rigor, a mortalidade é condição e finalidade da poesia, o que não exclui um tipo peculiar de esperança: a de que a poesia possa tornar-se exercício espiritual que prepara para o fim.

\begin{abstract}
Verdade mais absoluta dos seres viventes, a morte não deixa de inquietar profundamente a literatura. As obras literárias constroem representações diferentes que vão do macabro ao lúgubre, do terrível ao fascinante, do físico ao metafísico, do demoníaco ao divino, expondo as categorias do paradoxo da vida humana. Assim, a presença da morte na literatura, certamente a matriz de todos os outros temas, constitui um campo vasto e complexo, que se abre para as variadas abordagens críticas. (ZURCHI apud SILVA, 2009, p. 265).
\end{abstract}

Em Da morte. Odes mínimas, ainda, as seis aquarelas produzidas pela própria autora e mostradas abaixo chamam-nos atenção. E além delas, para Alcir Pécora (2003), também é objeto de curiosidade a forma poética da "ode" aplicada por Hilst no tratamento da morte, que a toma, então, como objeto de celebração e dicção solene. Para ele, ainda, observando a tripartição horaciana que geralmente era admitida para a composição de odes - cívicas, báquicas e privadas -, apenas essas últimas, que também podemos nomear como "familiares", têm semelhanças com as produzidas por Hilst. Porém, com diferenças notáveis, como aponta. Isso porque a poeta não se dirige a amigos ou parentes com o intuito de tecer as suas considerações de ordem reflexiva ou moral, mas somente para a morte, para a sua própria morte, sua única interlocutora nas odes.

A esse respeito, as aquarelas são elucidativas, e não devem ser desprezadas: têm todas cores quentes, vivas, e não apresentam nenhuma forma imediatamente reconhecível como fúnebre, temível ou macabra. As cenas são ensolaradas e apresentam cálidos passeios de seres que se metamorfoseiam em mistos e duplos. (PÉCORA, 2003, p. 8).

Seguem as aquarelas hilstianas descritas acima, que antecedem as odes em $D a$ morte. Odes mínimas: 


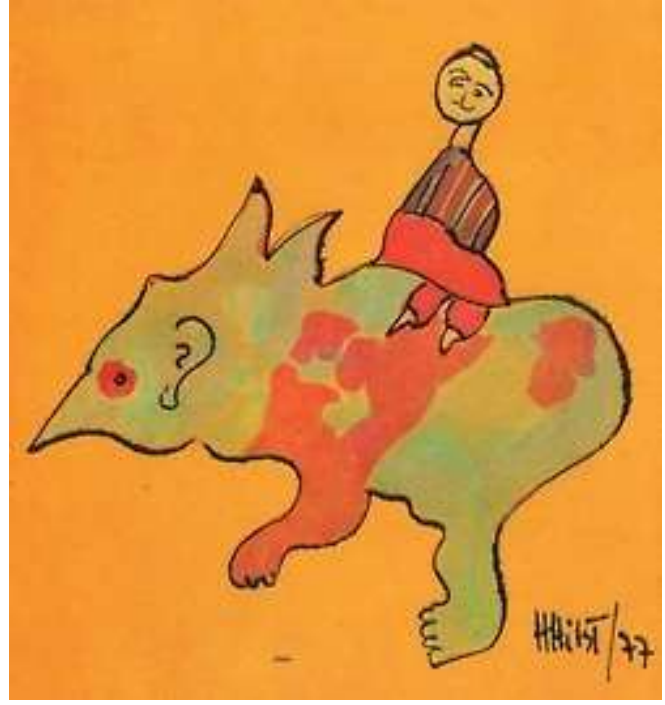

Rinoceronte elefante

Vivi nos altos de um monte

Tentando trazer teu gesto

Teu Horizonte

Para o meu deserto

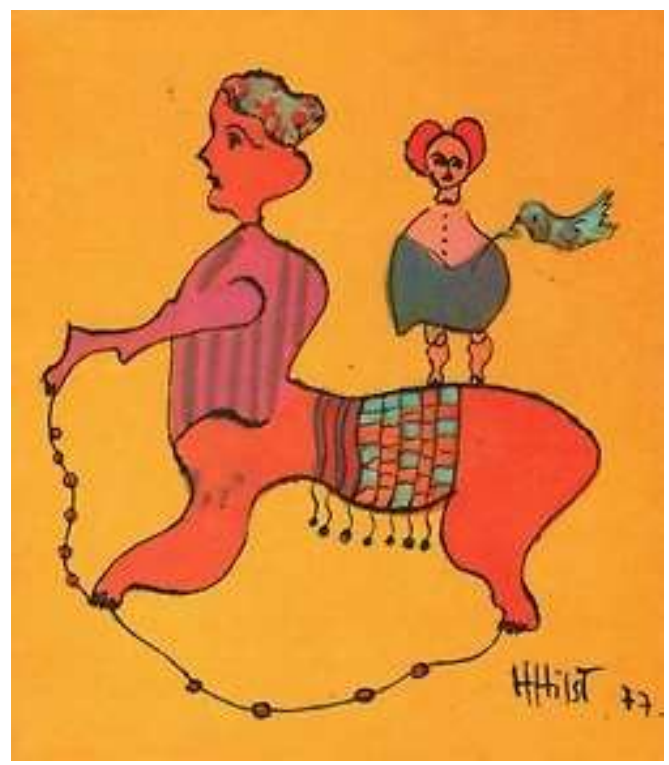

Fui pássaro e onça

Criança e mulher.

Numa tarde de sombras

Fui teu passo.

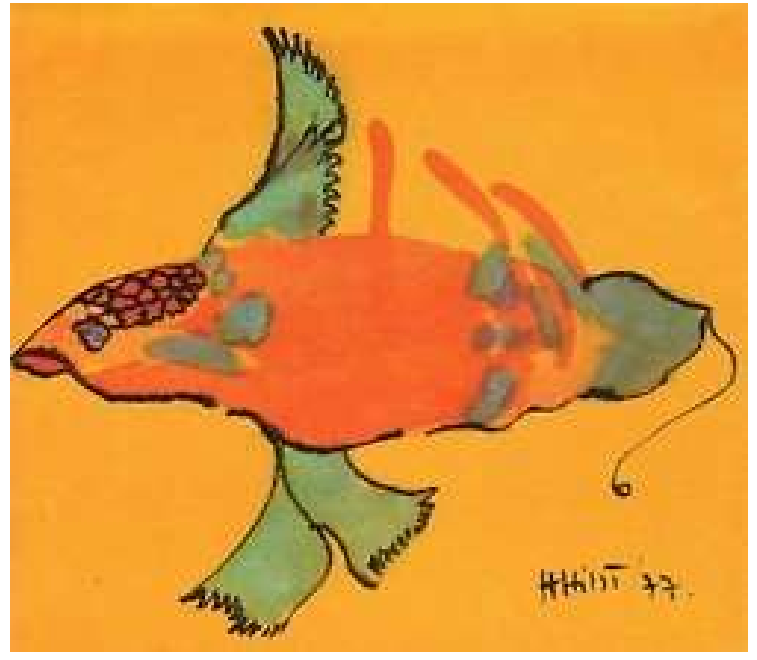

Um peixe raro de asas

As águas altas

Um aguado de malva

Sonhando o Nada.

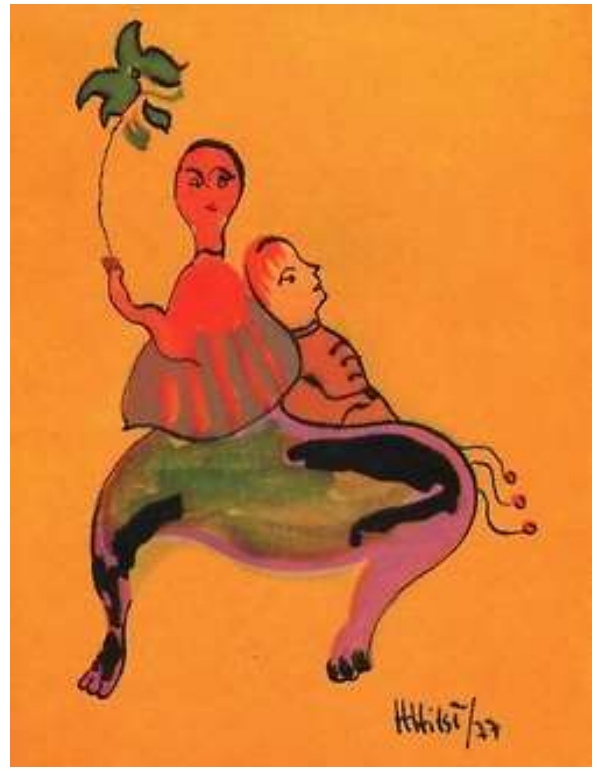

E descansavas nos meus costados Um ramo verde minha bandeira No meu vestido uns encarnados Docilidade tua Eu tua inteira. 


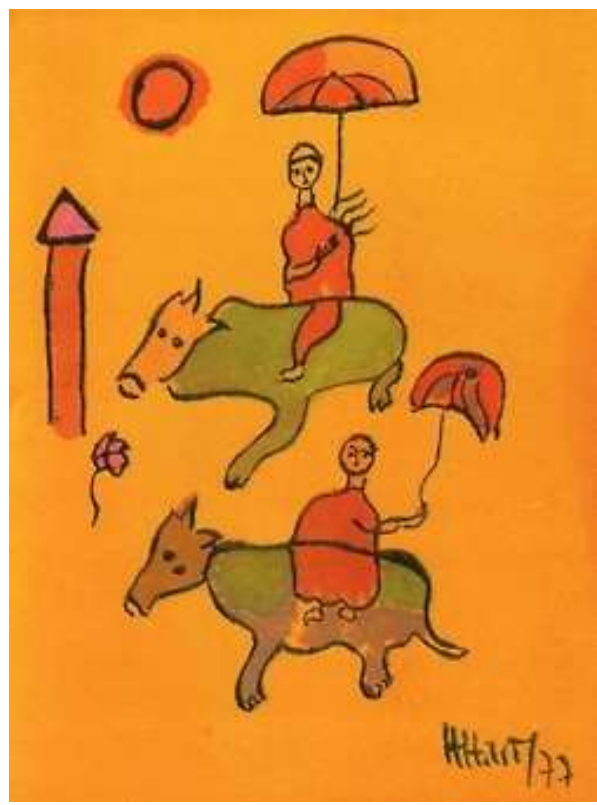

Montado sobre as vacas

Meu duplo e eu.

E guarda-sóis de fogo

E um sol de fráguas.

Mas cérebro e cascos

No breu

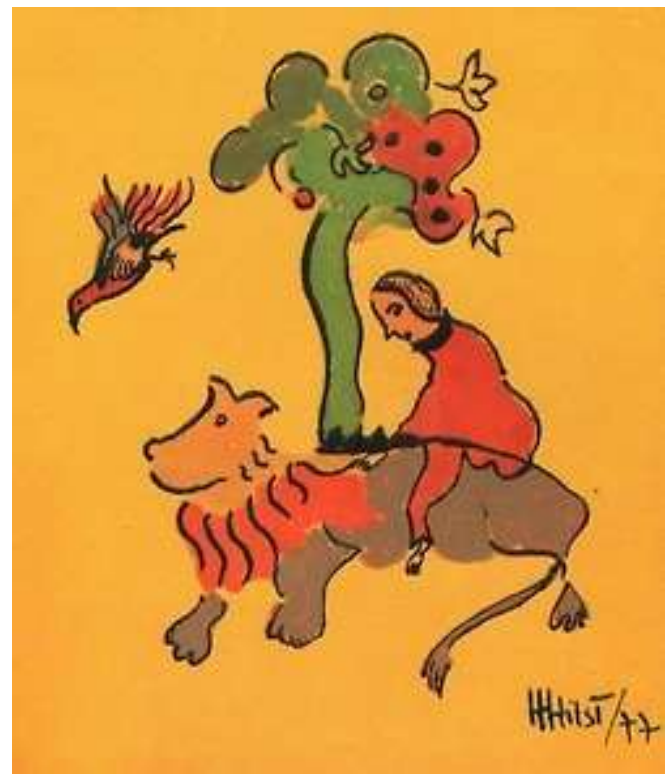

Sonhei que te cavalgava, leão-rei.

Em ouro e escarlate

Te conduzia pela eternidade

À minha casa. 
Durante a leitura das odes mínimas hilstianas, percebemos constantemente uma eufemização da morte, que ganha no decorrer do livro diversas nomeações: "Cavalinha", "Insana", "Palha", "Praia", "Velhíssima-Pequenina", dentre tantos outros. E suas “Aquarelas", segundo Souza (2009), são prova de que, se não podemos vencer Cronos e Tanatos, podemos criar uma discreta amizade que os torne menos tenebrosos. Esse é também o efeito produzido pelos variados e excêntricos nomes dados à morte. De qualquer forma, ainda consoante Souza (2009), o que se tem nos seis poemas de "Aquarelas" é a tentativa da poeta de trazer a morte para seu universo familiar, inserindo a imagem do duplo com a nítida intenção de sombrear as definições de agente e paciente. E, acima de tudo, amenizar a força destruidora da morte. Além disso, observamos também uma estreita relação entre Eros e Tanatos. O amor e a morte, consoante Coelho, desde suas origens míticas, andam sempre essencialmente unidos. E em Da morte. Odes mínimas, trava-se um diálogo com a própria morte, enfrentando-a, "como a grande realidade que permanece tão misteriosa para os homens de hoje, como o era nas origens do tempo" (COELHO, 1999, p. 75), anulando-se, assim, a distância entre si e sua própria morte, entrando, ainda de acordo com a autora imediatamente supracitada, na intimidade dessa temerosa figura, revelando-a essencialmente participante da vida.

Ainda quanto aos que permanecem a gozar a vida, há também alívio, porque a vida lhes foi poupada e, afinal, o ego se salva, parecendo mesmo, para este, que a morte nunca virá, que a morte está inclusa na existência do outro, o qual sucumbirá. Essa impressão juvenil não representa a realidade. Ao menos, não quando se fala da obra de Hilda Hilst, que é inteiramente cruzada pela morte como um rio subterrâneo. $\mathrm{Na}$ narrativa, no teatro e na lírica, a morte está presente. (ALBUQUERQUE, 2011, p. 102).

A literatura de Hilda Hilst, então, de acordo com Castello, mexe com as duas últimas fronteiras da modernidade: a paixão e a morte. Aquela desorganiza e esta fulmina. $\mathrm{O}$ que faz desta algo à margem, distanciado do cotidiano pela modernidade. E Hilda, com todas as suas particularidades, insiste em escrever sobre ambos os temas. "Escreve de um lugar perigoso para os que pensam em eficiência, em rendimentos mensuráveis, em idoneidade, elegância e bom gosto. Isso desorienta aqueles que sustentam a “independência absoluta diante do real" (CASTELLO, 1999, p. 103), falácia desmontada pela habilidade de Hilst em sua ficção. Em Da morte. Odes mínimas, especificamente, 
Hilda, segundo Pécora (2003), ao tratar da morte, compõe odes basicamente como a construção de uma interlocução com a morte, testando um vocabulário capaz de celebrála adequadamente. Para tanto, esforça-se para buscar "seus nomes perecíveis", isso porque "descrevem a morte como ocorrência de certa duração e demora no cerne de uma existência particular, afetiva e moral" (PÉCORA, 2003, p. 8-9). Além disso, a poeta é movida por uma série de interrogações de natureza física (psíquico-erótica), como afirmou Coelho (1999, p. 67); e de natureza metafísica, centrada no além das aparências, em que a morte compõe o grande mistério da vida.

A grande poesia contemporânea vem sendo energizada por essas interrogações, que são vitais para o homem de hoje, vagante num mundo belo-horrível, que perdeu seu 'centro sagrado' (a Palavra Revelada de Deus, negada pela Ciência), e com ele também o sentido último da vida e de sua presença no mundo. Na poesia (e ficção) de Hilda Hilst, essas interrogações radicais surgem, obviamente, de uma tríplice voz: a do ser humano, a da mulher e a da poeta. Sendo que a essa última cabe a tarefa nomeadora: a da palavra demiúrgica que cria o Real. (COELHO, 1999, p. 67).

Na verdade, não é tarefa fácil discutir poesia moderna. Muitos chegaram a afirmar que ela é fuga da realidade. Berardinelli (2007), no entanto, afirma que poderíamos ler nessa poesia um retorno à realidade: a irrupção do não-formalizado e do não-formalizável no interior de uma poética que se esforça cada vez mais para organizar e dominar esteticamente os seus materiais. Um dos grandes críticos dessa poesia, Theodor W. Adorno, vê nessa lírica moderna - apontada como, em algumas tendências, antirrealista - um caráter crítico e utópico, de denúncia, mesmo que de forma indireta, enxergando nesse universo, destarte, uma certa resistência da arte frente ao universo que a cerca. "Sua distância da pura e simples existência se torna medida da falsidade e da ruindade. Ao protestar contra a existência, a poesia exprime o sonho de um mundo em que as coisas sejam de outro modo" (ADORNO apud BERARDINELLI, 2007, p. 33). Um mundo onde a mercadoria não exerça domínio sobre o homem, como vem acontecendo desde a revolução industrial, o que gera um verdadeiro "culto de coisas". Destarte, deve ficar claro que: "o conteúdo de um poema não é a mera expressão de emoções individuais. Pelo contrário, estas só se tornam artísticas quando, exatamente em virtude da especificação de seu tornar-forma estético, adquirem participação no universal" (ADORNO, 1983, p. 193-194). 
Tal universalidade não significa, para o autor, que o conteúdo de um poema exprima aquilo que todos vivenciaram. O mergulho no individuado é que eleva o poema ao universal, tendo, deste modo, raízes no particular. O risco que a lírica assume com tudo isso, para Adorno, é o de, devido a esse princípio de individualização, não garantir nunca o engendramento de validade, de autenticidade. Uma coisa, no entanto, é certa a essa lírica, não se pode, ao analisá-la, utilizar-se de categorias prévias, pré-estabelecidas. Pois, de acordo com Adorno, o procedimento tem de ser conforme a linguagem da filosofia, imanente. Destarte, a partir dos próprios objetos é que devemos criar conceitos para sua análise. E isso é o que tentaremos fazer mais adiante, quando da análise de alguns poemas de Hilst.

\begin{abstract}
A única verdade ou autenticidade possível da lírica está em seu alheamento diante do suporte e da garantia de esquemas intersubjetivos por meio dos quais a socialização salva e subsume em si o indivíduo. É a tomada de partido por uma 'individualização implacável' que permite a lírica exprimir sua mensagem e a verdade não manipulada do seu conteúdo social. A distância das coisas, o sentido de sua estranheza 'metafísica' e irrecuperabilidade lírica, assim como a solidão do indivíduo abismado em si mesmo e sem esperança de um resgate comunicativo imediato (tudo o que caracteriza o máximo grau da lírica moderna), falam sobretudo da sociedade em que essa lírica se exprime. (BERARDINELLI, 2007, p. 35).
\end{abstract}

Para Adorno, essa universalidade do conteúdo lírico é, todavia, essencialmente social. Isso porque, para o autor, só entende aquilo que o poema diz quem escuta em sua solidão a voz da humanidade. E vai mais além, afirmando que a própria solidão da palavra lírica é pré-traçada pela sociedade individualista.

Quando essa poesia moderna se refere a conteúdos tanto dos homens quanto das coisas, de acordo com Friedrich (1991), não as trata descritivamente, nem com um calor de ver e sentir íntimos. Ela nos conduz, para ele, ao âmbito do não-familiar, torna-os estranhos, deforma-os. Essa sensação pode ser sentida por muitos ao ler os poemas sobre a morte de Hilda Hilst, sua abordagem em nada lembra o tratamento dado à morte em conversas cotidianas. Isso se explica, pelo menos em parte, pelo fato de a poesia, como postula o autor imediatamente supracitado, não mais ser medida com base no que comumente se chama realidade, pois se desprendeu da ordem espacial, temporal, objetiva e anímica, construindo, assim, um universo particular, construído pela linguagem. Para Adorno, a idiossincrasia do espírito lírico contra a prepotência das coisas é uma forma de 
reação à coisificação do mundo, à dominação da mercadoria sobre os homens que se difundiu desde o começo da Idade Moderna, como já apontado. Com tudo isso, a lírica moderna perdeu seu vínculo com a matéria e se empenhou no seu próprio "eu" para reestruturá-la, apresentando, desse modo, várias especificidades e mostrando-se diferente do que se fazia anteriormente. Para Friedrich (1991), das três maneiras possíveis de comportamento da lírica - sentir, observar, transformar -, esta última domina a lírica moderna tanto no que diz respeito ao mundo quanto à língua. De fato, a linguagem utilizada na lírica moderna foge do discurso comunicativo predominante na sociedade, apresentando diversas particularidades. Em Hilda Hilst, o próprio vocabulário selecionado para compor os poemas que tratam da morte já demonstra um trabalho diferenciado com a linguagem: trançados, teias, avencas, passadiços, olaria, feixes, entre outros, que no dia a dia não são associados a esse "evento".

O paradoxo específico da formação lírica, a subjetividade que vira objetividade, está ligada àquela preeminência da forma linguística na lírica, de que provém o primado da linguagem na criação literária (Dichtung) em geral, até a forma da prosa. Pois a própria linguagem é algo duplo. Através de suas configurações ela se molda inteiramente às emoções subjetivas; um pouco mais, e se poderia chegar a pensar que somente ela as faz brotar e amadurecer. Mas ela continua a ser, por outro lado, o meio dos conceitos, aquilo que restabelece a referência irrenunciável ao universal e à sociedade. As mais altas formações líricas são, por isso, aquelas em que o sujeito, sem resíduo de mera matéria, soa na linguagem, até que a própria linguagem ganha voz. $\mathrm{O}$ autoesquecimento do sujeito, que se põe a dispor da linguagem como de algo objetivo, e o que há de imediato e involuntário em sua expressão são o mesmo: assim a linguagem estabelece a mediação entre lírica e sociedade no que há de mais intrínseco. Por isso a lírica se mostra mais profundamente garantida socialmente ali onde não fala segundo o paladar da sociedade, onde nada comunica, onde, ao contrário, o sujeito, que acerta com expressão feliz, chega ao pé de igualdade com a própria linguagem, ao ponto onde esta, por si mesma, gostaria de ir. (ADORNO, 1983, p. 198).

Essa poesia moderna evita, consoante Friedrich, a intimidade comunicativa, prescindindo da humanidade no sentido tradicional do vivido, do sentimento e até mesmo do eu pessoal do artista. Criando, deste modo, um universo particular em cada poema composto. "Este não mais participa em sua criação como pessoa particular, porém como inteligência que poetiza, como operador da língua, como artista que experimenta os atos de transformação de sua fantasia imperiosa” (FRIEDRICH, 1991, p. 17). A língua 
poética, destarte, adquire, ainda consoante o autor ora discriminado, o caráter de experimento, do qual emergem combinações não pretendidas pelo significado, ou melhor, só então criam o significado. Isso é o que se percebe no tratamento dado à linguagem nos poemas hilstianos, nos quais o significado de cada um só pode ser depreendido mediante compreensão da linguagem trabalhada pela poeta, como observaremos nos exemplos seguintes.

Entre as imagens recorrentes da morte, estão a de definhamento, destruição, esgotamento, ruína, entre outras bem diferentes das apresentadas por Hilda Hilst na ode VIII em Da morte. Odes mínimas. Nesse poema, a morte é metaforizada como um processo de edificação, de construção, indicados já nos dois primeiros versos: "Lenho, olaria, constróis/ Tua casa no meu quintal". Com isso, apresenta um novo conceito para a finitude humana: uma casa em construção. Porém, o fato de ter a morte sempre presente é semelhante ao observado em poemas de outros tempos, apesar de o intuito não ser o mesmo. A morte, no poema, não é algo que se deseja afastar ou encobrir. Enquanto, sempre próxima de sua interlocutora, constrói a casa em bases firmes, utilizando-se do material produzido em olarias, do madeiro de plantas, se solidificando e fortalecendo a cada instante, a morte é observada, fato declarado pela sua interlocutora no terceiro verso do poema: "E desde sempre te espio". O que mostra que tem consciência da sua condição mortal e do contínuo caminhar para essa definitiva morada.

Essa construção vagarosa, na qual a vida era tida como brevíssima e a morte, consequentemente, não tardava a chegar, é constatada nos versos subsequentes: "Linho e cal/ lenta a tua casa". E observada em outras odes do livro, como na ode I, na qual a morte é comparada a um "trançado de teias", trabalho lento e contínuo; ou num sentido inverso, mas também vagaroso, da corrosão causada pela ferrugem, outra metáfora atribuída à morte por Hilst na ode VI. Seja na edificação de uma casa, no trançado de teias ou na deterioração causada pela ferrugem, a morte se apresenta como algo que vai continuamente trabalhando a vida humana, estando ao lado do homem desde sempre, agindo silenciosamente até que chegue ao fim do vivente. Esse trabalho é evidenciado nos versos seguintes da ode ora analisada.

\footnotetext{
Nova crescendo agora

Nos meus cinquenta.

E madeirames e telhas

E escadas, tuas rijezas.
} 
A morte, como a casa, vai aos poucos crescendo e se enriquecendo, a cada novo elemento acrescentado: tijolo, madeira, telha. E mesmo em vida, como sugere o poema, a morte acompanha os seres humanos, e vai crescendo e se fortalecendo. Essa imagem é contrária àquela em que morrer significa o retorno ao pó. Destarte, a morte, como casa em construção, mais uma vez é tida como algo que não está em ruínas, pois é nova e firme, e cresce a cada novo ano de vida de sua interlocutora, pois ainda está sendo erigida sem interrupções, desde o nascimento ela começa a ser erguida silenciosamente. O silêncio da morte não constitui um empecilho para que esta de vez em quando se apresente, para que o homem não se esqueça da sua presença:

\author{
Vezenquando te volteias \\ Para que eu não me esqueça \\ Do instante cego \\ Quando me pedirás companhia. \\ Eu não me esqueço. \\ Te espio de hora em hora.
}

Mais uma vez, aparece na ode a questão da proximidade da morte que de vez em quando rodeia sua futura companheira. Esta que, por sua vez, não se esquece do instante cego em que irá habitar a casa da morte, espiando-a de vez em quando. Uma se mostra, a outra observa, numa relação amistosa. Na ode, a autora não apresenta esse momento como abrupto, a morte não é caracterizada como uma invasora que arrebatará violentamente a vida, ao contrário, pedirá sua companhia. Para Hilda, a morte é a passagem do terreno para o eterno. O que não está vinculado com a questão religiosa da conversão, não trazendo, portanto, ensinamentos com objetivo de levar o leitor a abandonar as vaidades e os prazeres que se tem em vida para se dedicar ao que é divino, objetivo da poesia de outrora. A imagem da casa remete à última e definitiva morada, lugar de recolhimento definitivo, o qual a interlocutora acredita reconhecer a qualquer momento: "Casa e começo, tua cara/. A qualquer tempo te reconheço".

Da morte. Odes mínimas é um livro construído de modo a se observar a aproximação da morte e as várias reações do sujeito poético a essa aproximação que, no poema acima, é mais entrevista que vista. Mas, nessa cortina que se entreabre, vê-se a construção da morada mortal e os prenúncios do instante mortal. A agonia e a angústia da morte são os 
motores para a fatura do discurso poético que se abre com força imagética de uma casa lentamente erguida. (ALBUQUERQUE, 2011, p. 123).

No século XVII, alguns objetos inanimados lembravam ao homem a sua condição de pó. Nas odes de Hilda, a morte está em todos os lugares, como exemplifica a ode XIII, que aponta que a morte está: "Funda, no mais profundo do osso./ Fina, na tua medula/ No teu centro-ovo". Estando, deste modo, em uma situação central na vida humana, presente não de modo superficial, mas sim de maneira profunda e marcante, além de presente sempre. "Paciente, colada às pontes/ Onde devo passar atada aos pertences da vida./ Em tudo és e estás.".

Para Lima (2008, p. 30), outros poetas se digladiaram com esse tema, produzindo resultados diversos. Como esse é um tema de risco, o poeta que o desenvolve tem de tomar cuidado a fim de não cair no senso comum, repetindo o que outros já disseram e pouco acrescentando à tradição. O que não é o caso de Hilda Hilst em Da morte. Odes mínimas, em que, ainda segundo o autor imediatamente supracitado, a visão poética apresentada dá um impulso novo à tradição lírica, propiciando um segmento temático plenamente desenvolvido em outras tradições poéticas. A poeta, com um trabalho diferenciado com a linguagem, aborda o tema de forma distinta do que muitos vinham fazendo, criando imagens diferentes, que perpassam pelo amor, pelo erotismo, pela sedução e até pelo tom de brincadeira, matizando-o com cores inéditas, apresentando uma consciência bastante acentuada da morte que se inicia desde o momento em que nascemos, construindo sua casa e tecendo suas teias. Identificando-a em locais diversos, o que não a impediu de tratar o tema de forma descontraída e com bastante humor, o que, entre outros trabalhos, fez do seu nome um dos principais na literatura contemporânea.

NOVAIS, Joseane Aguiar; MOREIRA, Marcello. The death in Hilda Hilst. Revista do Gel, v. 14, n. 2, p. 12-26, 2017.

Abstract: This paper discusses the book Da morte. Odes mínimas, by Hilda Hilst, specifically emphasizing the treatment given to death in her small odes, which are part of a disturbing work by virtue of the unique positioning of the creature who wrote them, called by critics as voluptuous. In this book, the author treats the finitude of life in a singular way, thinking of it without wanting to overcome it, emphasizing its slow and continuous process, which crowns an entire existence and is something intimate, serene 
and natural. Quite a different view of the pessimist presented throughout a tradition, where death was seen as somber, painful, something that causes fear.

Keywords: Hilda Hilst. Death. Odes. Poetry.

Submetido em: 09/01/2017.

Aceito em: 26/05/2017.

\section{Referências}

ADORNO, T. W. Lírica e Sociedade. In: BENJAMIN, W.; HABERMAS, I.; HORKHEIMER, M.; ADORNO, T. W. Os Pensadores. São Paulo: Abril Cultural, 1983.

AlBUQUerQue, G. A. S. de. Deus. Amor. Morte. E as atitudes líricas na poesia de Hilda Hilst. Manaus: Editora Valer, 2011.

BERARDinelli, A. Da Poesia à Prosa. São Paulo: Cosac Naify, 2007.

Cadernos de Literatura Brasileira. Hilda Hilst. Instituto Moreira Salles, n. 8, 1999.

CALLIA, M. H. P. Introdução. In: OLIVEIRA, M. F. de; CALLIA, M. H. P. (Org.). Reflexões Sobre a Morte no Brasil. São Paulo: Paulus, 2005.

CARVALHO, V. A. A vida que há na morte. In: BROMBERG, M. H. P. et al. Vida e morte: laços da existência. São Paulo: Casa do Psicólogo, 1996.

CAStello BRAnCO, L. A traição de Penélope. São Paulo: Annablume, 1994.

CINTRA, E. C.; SOUZA, E. N. F. e. Roteiro Poético de Hilda Hilst. Minas Gerais: EDUFU, 2009.

COELHO, N. N. Por que me fiz poeta? Da morte. Odes mínimas. In: Cadernos de Literatura Brasileira. Hilda Hilst. Instituto Moreira Salles, n. 8, p. 66-79,1999.

CRISTÓBAL, V. Precedentes clásicos del género de la oda. In: La oda. Universidad de Sevilla-Universidad de Córdoba, 1993.

DIAS, M. H. M. Agda em dois tempos: a obsessão por corpo e linguagem em QADÓS de Hilda Hilst. In: CINTRA, E. C.; SOUZA, E. N. F. e. Roteiro Poético de Hilda Hilst. Minas Gerais: EDUFU, 2009. p. 23-41.

FRIEDRICH, H. Estrutura da Lírica Moderna (da metade do século XIX a meados do século XX). São Paulo: Livraria Duas Cidades, 1991. 
GRANDO, C. A poesia de Hilda Hilst: o poder transformador da palavra. In: CINTRA, E. C.; SOUZA, E. N. F. e. Roteiro Poético de Hilda Hilst. Minas Gerais: EDUFU, 2009. p. 321-333.

GUIDO, H. Pessimismo metafísico e sensibilidade poética: algumas aproximações entre a filosofia e a poesia de Hilda Hilst. In: CINTRA, E. C.; SOUZA, E. N. F. e. Roteiro Poético de Hilda Hilst. Minas Gerais: EDUFU, 2009. p. 191-212.

HILST, H. Da Morte. Odes mínimas. São Paulo: Editora Globo, 2003.

LIMA, J. C. F. de. As amantes: uma leitura de Da morte. Odes mínimas de Hilda Hilst. 2008. 110 f. Dissertação (Mestrado em Literatura) - Instituto de Letras, Universidade de Brasília, Brasília, 2008.

PÉCORA, A. (Org.). Por que ler Hilda Hilst. São Paulo: Editora Globo, 2000. . Nota do organizador. In: HILST, H. Da morte. Odes mínimas. São Paulo: Editora Globo, 2003. p. 7-10.

SILVA, L. C. A. da. Hilda Hilst: a literatura e a morte. In: CINTRA, E. C.; SOUZA, E. N. F. e. Roteiro Poético de Hilda Hilst. Minas Gerais: EDUFU, 2009. p. 263-281.

SOUZA, M. R. T. Do corpo ao texto: a mulher inscrita/escrita na poesia de Hilda Hilst e Ana Paula Tavares. São Paulo: FFLCH-USP, 2009. 